\title{
PERCEPTION OF FAMILY ENVIRONMENT WITH RUSSIAN ADOLESCENT TWINS: POSSIBLE GENOTYPE-ENVIRONMENT CORRELATION
}

\author{
Philipp I. Barsky ${ }^{*}$ \\ Elena D. Gindina* \\ Marina M. Lobaskova ${ }^{* *}$ \\ Sergey B. Malykh \\ ${ }^{*}$ Psychological Institute, Russian Academy of Education, Moscow \\ ${ }^{* *}$ Udmurtia State University, Izhevsk
}

\begin{abstract}
Gene-environment correlations have been studied in behavior genetics since the beginning of the 1980s, including genetic effect on the perceived family environment; however, the majority of studies have been based on retrospective self-reports. The current study is meant to analyze the sources of variance (complementary genetic factors, shared and non-shared environmental variance) in perceived family environment with Russian adolescent twins. Perception of family environment was measured with the Russian version of Family Environment Scale (Moos \& Moos, 1981). The structural equation model in "Mx" (Neale, Boker, Xie, \& Maes, 2004) was employed to estimate the influence of genetic and environmental factors on adolescents' self-reports. The environmental variance components are prevalent for most FES scales ( 6 of 10). The shared environment was significant for 3 primary grades and the Organization factor, the complementary genetic variance was revealed for 2 primary grades and the ExpressivenessControl super-order factor. These results are generally consistent with previously reported moderate heritability of FES scales, although the heritabilities for the Conflict scale and the Structure super-order factor appear to be relatively high. The gene-environment correlation might be a possible explanation for these findings.
\end{abstract}

Keywords: perceptions of family environment, environment, genotype, twins, gene-environment correlation, Family Environment Scale, adolescence.

This study was supported by a grant from Federal Agency for Science and Innovations of Russian Federation, contract No. 02.740.11.0376. 
The study of family environment is a rapidly developing cross-disciplinary area that combines research in developmental psychology and behavior genetics (Neiderhiser, Reiss \& Hetherington, 2007; Plomin, Asbury, \& Dunn, 2001; Turkheimer \& Waldron, 2000). Behavior genetics is likely to be "the best available" approach for studying environmental influences on development (Plomin \& Caspi, 1999, p. 251) because it allows partition of phenotypic variance into genetic and environmental components, when environmental components are free from any genetic influences. Behavior genetics impels different kinds of environment studies: a) the estimation of summary contribution of environmental variance to phenotypic variance of a trait, where the real environmental effect is not measured but estimated as a residual of variance that is not accounted for by genetic variance; b) the studies of perceived environment, where reports on different aspects of the environment are considered to be phenotypes and contributions of genetic and environmental variance to this phenotype are estimated; and c) the studies of an objectively measured environment, where measured environmental variables are analyzed along with genetically informative data.

The first approach previously mentioned to studying environmental factors as residuals from heritability in behavior genetics is the oldest, simplest, and the least informative method. Present-day estimations of heritability coefficients and residuals are often used as proxies in more complex multivariate research designs. The objective measurement of environmental variables is a labor-intensive and sometimes empirically unfeasible enterprise. Yet studies of the environment as perceived by family members and other experts are relatively easy to conduct and they can yield quite informative data.

During the last two decades, not only have empirical studies of the environment expanded and developed in behavior genetics (Barsky, 2007; Rutter, 2007; Turkheimer \& Waldron, 2000), but theories of interactions between genes and the environment have also been reconsidered and redefined (Belsky, Bakermans-Kranenburg, \& van Ijzendoorn, 2007; Cole, 2009; Champagne \& Mashoodh, 2009; Kim-Cohen \& Gold, 2009; Rutter, 2006). Behavior genetics has evolved into the study of gene-environment interplay instead of separate segregating genetic and environmental variance components for specific traits (Moffitt, Caspi, \& Rutter, 2006; Rutter, 2007). According to Rutter, Moffitt, and Caspi (2006), four kinds of gene-environment interplay can be distinguished: 
a) epigenetic processes, in which environmental factors effect gene expression; b) the influence of the environment on the level of heritability; c) gene-environment correlation; and d) the interaction of specific genes and specific environments. The gene-environment correlation (Plomin, Defries, \& Loehlin, 1977) is one of the most widely studied forms of gene-environment interplay in behavior genetics. The simplest way of estimating the gene-environment correlations in people, when direct experimentation is unfeasible, is via implementing a quasi-experimental design of quantitative (biometrical) genetics. Typically, self-reports or observations of specific aspects of environments are measured like any other kinds of phenotypes, and the data are subsequently subjected to genetic model-fitting analyses. Gene-environment correlations are now generally accepted as not being exceptional (as it was assumed several decades ago), but rather universal phenomena (e.g., Rutter, 2006).

Empirical studies of gene-environment correlations generally focus on self-reports of different dimensions of family relationships: parentchild relationships, within-pair siblings' and twin relationships; and, sometimes, peer, school and other kinds of extra-familial relationships. Using observational methods is still rare (O'Connor, Hetherington, Reiss, \& Plomin, 1995); indeed, the most widely used approach for obtaining data on environment is still based on twins' retrospective self-reports (Chipuer \& Villegas, 2001). Like any other method, studies of perceived environment (Herndon, McGue, Krueger, \& Iacono, 2005; Moos, 1975) have their own strong and weak points. On the one hand, the answers to questionnaires are subjective evaluations because they are heavily influenced by informants' personal experiences (Plomin \& Bergeman, 1991). Yet who - if not the very informants - can evaluate the most important aspects and impressions of their own lives in their environment? Meanwhile, despite the individuality of each person's experience, it is reasonable to assume that standardized questionnaires allow - to a certain extent - the unification of characteristics of interests.

One of the most popular instruments for assessing family environments is the Family Environment Scale (FES) (Moos, 1974; Moos \& Moos, 1994). Using expert opinions, Moos (1974) selected three primary dimensions of social climate in various social institutions, such as family, class, therapeutic group, workgroup, and other communities - primary dimensions come as the following: Relationships, Personal Growth, and System Maintenance dimensions. According to Moos, family can be sufficiently 
characterized by specifying the kind of prevailing personal relationships, description of the encouraged ways in personal growth, and through discovering its organizational structure. The Relationships dimension determines the extent to which family members feel their belonging to the family and are proud of it, the extent of freedom of self-expression in the family, and the conflict level among the family members. The Personal Growth dimension reflects prevailing areas of personality development in the family (e.g., independence, achievements, intellectual and cultural activities, moral-religious attitudes, and various forms of recreational activities). Finally, the System Maintenance dimension includes information on the importance of structure and organization in the family, to which extent the centralized control is sustained in the family, and how flexible the family reactions are to life challenges and changes.

Despite the fact that several hundred studies have been conducted employing FES during the last 35 years, the debates on validity of the technique remain urgent (Boyd, Gullone, Needleman, \& Burt, 1997; Munet-Vilaro \& Egan, 1990; Roosa \& Beals, 1990; Sanford, Bingham, \& Zucker, 1999; Waldron, Sabatelli, \& Anderson, 1990). The relatively low internal consistency of the original questionnaire has been criticized by adherents of precise psychometrics (Boyd et al., 1997; Loveland-Cherry, Youngblut, \& Kline-Leidy, 1989; Roosa \& Beals, 1990; Sanford, Bingham \& Zucker, 1999). Yet Moos (1990) emphasizes that the psychometric weakness is the reverse-side of the strong basis of the method - that is, its wide coverage of different aspects of family life (Moos, 1990). The factor-analytical studies of the questionnaire have also yielded ambiguous results: Some authors reported two factors with relatively similar content (Boake \& Salmon, 1983; Chipuer \& Villegas, 2001; Fowler, 1981; Hur \& Bouchard, 1995; Loveland-Cherry et al., 1989; Oliver, May, \& Handal, 1988; Rowe, 1983), while others commented on three factors that sometimes confirmed the original dimensional structure proposed by Moos (Bloom, 1985; Bloom \& Naar, 1994), or - more often - failed to confirm it (Bouchard \& McGue, 1990; Gondoli \& Jacob, 1993; Halloran, Ross, \& Carey, 2002; Kronenberger \& Thompson, 1990; Saucier, Wilson, \& War$\mathrm{ka}, 2007)$. In general, the original three dimensions, as Moos planned were not reproduced in most of factor-analytical studies of FES. Nevertheless, the questionnaire is still one of the most widely used instruments in clinical practice as well as in fundamental research, including behavior genetics (e.g., Bouchard \& McGue, 1990; Herndon et al., 2005; 
Jang, Vernon, Livesley, Stein, \& Wolf, 2001; Plomin \& Bergeman, 1991; Plomin, Loehlin, \& DeFries, 1985; Rowe, 1983; Vernon et al., 1997).

Rowe $(1981$; 1983) conducted the first studies of family environment in the field of behavior genetics. Rowe found that monozygotic (MZ) adolescent twins tend to report much more similar evaluations of parental "warmth" than dizygotic (DZ) twins, but they did not differ in their evaluations of parental "control." This difference in MZ and DZ coordination could be interpreted as an indication of genetic influence on the individual differences in the parental warmth dimension of perceived family environment. Results submitted by the Colorado Adoption Project (Daniels \& Plomin, 1985; Deater-Deckard, Fulker, \& Plomin, 1999; Plomin, Loehlin, \& DeFries, 1985), the Swedish Adoption / Twin Study of Aging (Plomin, McClearn, Pedersen, Nesselroade, \& Bergeman, 1988), Minnesota Study of Twins Reared Apart (Bouchard \& McGue, 1990; Krueger, Markon, \& Bouchard, 2003), the Western Ontario Twin Project (Vernon et al., 1997), and the large-scale family longitude Nonshared Environment in Adolescent Development (Plomin, Reiss, Hetherington, \& Howe, 1994; Reiss, Neiderhiser, Hetherington, \& Plomin, 2000) agree on the fact that a noticeable portion of individual differences in perceived environment can be correlated with children's genetic differences. As Plomin and Bergeman (1991) emphasized in their review, it is not correct to declare that a variable is environmental until the sources of its variance are revealed using behavior genetics methods. Plomin and Bergeman suggested that subjective reports on environment - as in any other questionnaire data - must reflect to a certain extent informants' personality traits as at least a portion of variance in personality is associated with genetic differences. This hypothesis has received limited support from empirical studies as the results from research that addressed correlations of personality traits and perceived environment are ambiguous (e.g., Krueger et al., 2003; Vernon et al., 1997).

Another circumstance complicates the situation even further: most of the behavior genetic studies of perceived environment, with some exceptions (Herndon et al., 2005; Plomin et al., 1989; Rowe, 1983), analyzed retrospective data in that the questionnaires asked adults and seniors to recall their experiences from childhood and adolescent years. Thus, it is very likely that their recollections were "filtered through" their personalities, as Plomin and Bergeman (1991) put it, although it is still not clear whether the same would be true for reports on their present lives. 
Herndon et al. (2005) addressed this question by studying genetic and environmental influences on adolescent male twins' perceptions of their current family environment using the FES questionnaire. In contrast to the results of previous studies, Herndon et al. reported comparable moderate heritability for all FES scales and for both factors that emerged from analysis - that is, "acceptance / support" and "control / structure." Yet, conclusions drawn from the study from Minnesota in the United States are somewhat limited as they were based on a male-only sample with a rather narrow age limits (17 years old only). Taking into account the well-known differences in gender role models - not to mention the biological factors directly related to genes - the study of genetic and environmental factors in the current environment as perceived by adolescents of both sexes is necessary.

The aim of the current study is to investigate the genetic and environmental etiology of individual differences in adolescents' perceptions of family environment. As noted by Herndon and his colleagues (2005), the upper limit of 17 years of age (with a wider range) is chosen because adolescents tend to leave home after this point and start experiencing rapid life changes (e.g., entering college); meanwhile, children still living in the same family, are expected to rate more or less the same objective events. The lower age point (the start of teenage years) in our study is based on children's development of general cognitive ability, which allows for the use of paper-and-pencil questionnaires.

\section{Methods}

\section{Participants}

Our sample comprised 450 male (52\%) and female (48\%) twins from 11 to 17 -year-old $(M=14, S D=2)$ from Izhevsk, Moscow and St. Petersburg in the Russian Federation. The entire sample is Caucasian, of either Russian or Udmurtian ethnicity, which is representative of the general population of the regions studied. Zygosity was diagnosed using a modified version of Nichols and Bilbro's (1966) questionnaire, which has a reported accuracy of more than $90 \%$. We have identified 75 pairs of $M Z$ twins, 63 pairs of same-sex DZ twins, and 66 pairs of different-sex DZ twins. We were unable to identify the zygosity of 21 twin pairs; their data were included only in the common psychometric analyses, but not in genetic analyses. Overall, we had 204 twin pairs eligible for quantitative genetic analysis. 


\section{Measures}

The Russian version of the FES (Moos, 1974; Moos \& Moos, 1981; 1994) questionnaire, adapted by S. Kupriyanov (Eidemiller, Dobryakov, \& Nikolskaya, 2003), was used to assess the perceptions of current family environment. The original version of FES had two forms - R (Real) and I (Ideal), for assessment of the real and ideal wishful family characteristics, respectively. We used only the R form in our study. FES consists of 10 nine-item scales (every item is scored "true / false"), each designed to measure a separate aspect of family environment: Cohesion, Expressiveness, Conflict, Independence, Achievement Orientation, IntellectualCultural Orientation, Moral-Religious Orientation, Organization, and Control. Each participant completed the questionnaire using a paperand-pencil format.

\section{Statistical analyses}

Reliability, factor analysis, correlations and regressions were computed using SPSS 13. The within-pair correspondence was assessed through Fisher's intraclass correlation coefficient. The influence of sex and age in the variation of scales and factor scores was controlled by correcting the scores on age and sex using regression, as suggested by McGue and Bouchard (1984).

The "Mx" computer program (Neale et al., 2004) was employed for biometrical model-fitting. Model-fitting (or structural equation modeling) is a statistical technique for testing complex hypotheses about variance structure (Loehlin, 2004). The method is based on mathematical algorithms, which allow the comparison of theoretical variance components to empirical data. "Mx" allows for the variance in each FES scale to be decomposed into that due to genetic (A), shared environment $(\mathrm{C})$, and nonshared environment (E) sources of variation according to standard biometrical methods. The full model (i.e., the one specifying that they are affexted from $A, C$, and $E$ ) was first fit the data for each scale and factor and then modified, with a series of reduced models tested. The AE model tested no effect of shared environment, the CE model tested no genetic effect, and the $\mathrm{E}$ model tested no effect of either shared environment or genetics. In order to use all available information and minimize bias due to none-response, analyses were conducted using the raw data option in "Mx." A variant of maximum-likelihood approach (full-information maximum likelihood) was used for model-fitting with the raw 
data. The fit of nested models was evaluated using a $-2 * \log$-likelihood (a $\chi^{2}$ equivalent) and the Akaike Information Criterion (AIC) (Akaike, 1987). A more negative AIC value indicates a better fit.

\section{Results}

\section{Measures' reliability}

The initial psychometric analysis of FES included several stages: reliability analyses, factor analysis, and correction of data for the influence of age and sex.

The internal consistency of the FES scales was assessed using Cronbach's alpha. The scales were modified by deleting items with negative item-scale correlations after the initial assessment, except for Intellectual-Cultural Orientation, which could not be corrected. The results of reliability analyses and correction are presented in Table 1.

Table 1

Reliabilities of FES scales before and after correction

\begin{tabular}{|l|c|c|c|c|}
\hline \multicolumn{1}{|c|}{ Scale } & $\begin{array}{c}\text { Cronbach's } \alpha \\
\text { before cor- } \\
\text { rection }\end{array}$ & $\begin{array}{c}\text { Number of } \\
\text { items before } \\
\text { correction }\end{array}$ & $\begin{array}{c}\text { Cronbach's } \alpha \\
\text { after correc- } \\
\text { tion }\end{array}$ & $\begin{array}{c}\text { Number of } \\
\text { items after } \\
\text { correction }\end{array}$ \\
\hline 1) Cohesion & .23 & 9 & .56 & 6 \\
\hline 2) Expressiveness & .17 & 9 & .38 & 6 \\
\hline 3) Conflict & .44 & 9 & .58 & 8 \\
\hline 4) Independence & .16 & 9 & .36 & 6 \\
\hline 5) Achievement & .13 & 9 & .45 & 5 \\
\hline 6) Intellectual-Cultural & .54 & 9 & - & - \\
\hline 7) Active-Recreational & .60 & 9 & .62 & 8 \\
\hline 8) Moral-Religious & .41 & 9 & .56 & 7 \\
\hline 9) Organization & .56 & 9 & .59 & 8 \\
\hline 10) Control & .31 & 9 & .42 & 5 \\
\hline
\end{tabular}

As Table 1 indicates, hardly any of the FES scales displayed a sufficiently high alpha coefficient. After the deletion of uncorrelated items, it became possible to reach 0.6 for 5 scales (Cohesion, Conflict, Active- 
Recreational, Moral-Religious, and Organization), but the alphas for the remaining 4 scales were still unsatisfactory. Nevertheless, the informative value of the scales is important, and we included them in further analyses, although we cautiously interpreted the results - especially for Expressiveness, Independence, and Achievement.

\section{Factor analysis}

An exploratory principal components factor analysis of FES scales was conducted using Varimax rotation on the scales after carrying out corrections for internal consistency. The rotation yielded an interpretable three-factor solution (see Table 2). The first Structure factor included Organization, Cohesion, Conflict, and Independence, with significant loadings for Achievement Orientation. The second Expressiveness-Control factor included Expressiveness, Moral-Religious Orientation, Control and Achievement Orientation. The third Activities factor was clearly interpretable; it included Intellectual-Cultural Orientation and ActiveRecreational Orientation scaled with exclusively high loadings. Overall, three factors explained $54 \%$ of the variance. The solution obtained resembles the results of Oliver, May, and Handal's (1988) study, although the factor loadings are different - the last being not at all unexpected.

Table 2

Varimax-rotated factor loadings for 10 FES scales for the combined sample of twins

\begin{tabular}{|l|c|c|c|}
\hline \multirow{2}{*}{\multicolumn{1}{|c|}{ Scale names }} & \multicolumn{3}{c|}{ Components } \\
\cline { 2 - 4 } & 1 & 2 & 3 \\
\hline Conflict & .794 & & \\
\hline Organization & .702 & & \\
\hline Independence & .569 & & \\
\hline Cohesion & .566 & .330 & \\
\hline Expressiveness & & .679 & \\
\hline Moral-Religious & & .600 & \\
\hline Control & .381 & .582 & \\
\hline Achievement & .470 & .566 & \\
\hline Intellectual-Cultural & & & .819 \\
\hline Active-Recreational & & & .814 \\
\hline
\end{tabular}




\section{Descriptive statistics}

Mean and standard deviations for the $\mathrm{MZ}$ and $\mathrm{DZ}$ twins are presented in the Table 3. The significance of mean differences between MZ and DZ groups was assessed using $t$-tests (see $p$-values in Table 3 ). The differences in means were statistically significant for 2 of 10 scales (Expressiveness and Achievement Orientation) and one factor (ExpressivenessControl). With regard to the fact that no significant differences existed for the remaining 8 scales and 2 factors and that the found mean differences did not exceed $10 \%$, we do not consider that obtained values should prevent further analyses.

In comparison with the obtained means from Herndon and colleagues' (2005) study, which - as reported by the authors - correspond well to normative data (Moos \& Moos, 1981), the means for eight scales in our data are of comparable value whereas but two scales differ. The mean for the Conflict scale in the sample of Russian twins is noticeably higher than in the American sample while the mean for Moral-Religious Orientation is noticeably lower.

Table 3

Means and standard deviations for MZ and DZ twins on FES primary scales and factors

\begin{tabular}{|c|c|c|c|}
\hline Scale (factor) & $\mathrm{MZ}$ & $\mathrm{DZ}$ & $\mathrm{p}$ \\
\hline \hline 1) Cohesion & $.64(.19)$ & $.64(.18)$ & .90 \\
\hline 2) Expressiveness & $.48(.25)$ & $.58(.25)$ & .00 \\
\hline 3) Conflict & $.71(.21)$ & $.69(.24)$ & .62 \\
\hline 4) Independence & $.74(.21)$ & $.71(.20)$ & .23 \\
\hline 5) Achievement & $.69(.26)$ & $.77(.22)$ & .00 \\
\hline 6) Intellectual-Cultural & $.48(.22)$ & $.49(.23)$ & .66 \\
\hline 7) Active-Recreational & $.47(.24)$ & $.49(.23)$ & .46 \\
\hline 8) Moral-Religious & $.35(.21)$ & $.40(.25)$ & .08 \\
\hline 9) Organization & $.66(.23)$ & $.66(.25)$ & .91 \\
\hline 10) Control & $.57(.25)$ & $.63(.29)$ & .06 \\
\hline Factor I - Structure & $.05(1.0)$ & $-.02(1.0)$ & .52 \\
\hline Factor II - Expressiveness & $-.25(1.0)$ & $.19(1.0)$ & .00 \\
\hline Factor III - Activities & $-.03(1.0)$ & $-.01(1.0)$ & .87 \\
\hline
\end{tabular}




\section{Twin correlations}

The twin intra-class correlations for 10 scales and 3 least-squares estimated factor scales are presented in Table 4 (note: $N$ represents the number of pairs, not persons). For 3 of the 10 scales (Achievement Orientation, Moral-Religious Orientation, and Control) as well as for the Expressiveness-Control factor, MZ correlations exceeded those of DZ twins. Although these differences were not that big, they are in a range that could be well considered a chance finding for this sample size (.06-.14).

Table 4

Twin correlations for FES scales and factor scores

\begin{tabular}{|l|c|c|}
\hline \multicolumn{1}{|c|}{ Scale (factor) } & MZ N=75 & DZ N=63 \\
\hline \hline 1) Cohesiveness & .55 & .40 \\
\hline 2) Expressiveness & .60 & .55 \\
\hline 3) Conflict & .75 & .48 \\
\hline 4) Independence & .63 & .51 \\
\hline 5) Achievement & .63 & .75 \\
\hline 6) Intellectual-Cultural & .69 & .57 \\
\hline 7) Active-Recreational & .74 & .63 \\
\hline 8) Moral-Religious & .64 & .76 \\
\hline 9) Organization & .72 & .66 \\
\hline 10) Control & .32 & .46 \\
\hline \hline Factor I - Structure & .84 & .54 \\
\hline Factor II - Expressiveness & .61 & .67 \\
\hline Factor III - Activities & .78 & .67 \\
\hline
\end{tabular}

\section{Model Fitting}

Biometric models were fit for the 10 primary FES scales and 3 factor scores. For all scales and factors, the ACE model provided a good fit for the twin data and fit significantly better than the E model, indicating the need to model effects to account for twin similarities. Parameter estimates and associated 95\% confidence intervals are reported in Table 5. The full ACE model provided the best fit for four scales (Cohesion, 
Independence, Intellectual-Cultural Orientation, Organization) and the Activities factor. The AE model (additive genetic effects and nonshared environment) fit best for two scales (Conflict and Control) and the Structure factor. The additive genetic factors component (A) was significant for all three (the confidence intervals did not include zero). The environmental CE model appeared to fit best for the other four scales (Expressiveness, Achievement Orientation, Active-Recreational Orientation, Moral-Religious Orientation) and the Expressiveness-Control factor. The shared environment variance component (C) was shown to be significant for three scales and the last named factor.

Table 5

Standardized variance estimates and model fit statistics for FES primary scales and factor scores

\begin{tabular}{|l|c|c|c|c|c|c|}
\hline \multicolumn{1}{|c|}{ Scale (factor) } & $\mathrm{A}$ & $\mathrm{C}$ & $\mathrm{E}$ & $-2 \mathrm{LnL}$ & $\mathrm{df}$ & $\mathrm{AIC}$ \\
\hline \hline 1) Cohesion & $.22(.00-.54)$ & $.15(.00-.45)$ & $.62(.45-.82)$ & 751.255 & 265 & 221.255 \\
\hline 2) Expressi-veness & - & $.41(.26-.54)$ & $.59(.46-.54)$ & 723.819 & 266 & 191.819 \\
\hline 3) Conflict & $.62(.47-.73)$ & - & $.38(.27-.53)$ & 719.312 & 268 & 183.312 \\
\hline $\begin{array}{c}4) \text { Indepen- } \\
\text { dence }\end{array}$ & $.21(.00-.60)$ & $.25(.00-.53)$ & $.55(.39-.72)$ & 698.591 & 265 & 168.591 \\
\hline 5) Achievement & - & $.51(.37-.62)$ & $.49(.38-.63)$ & 731.208 & 266 & 199.208 \\
\hline $\begin{array}{c}\text { 6) Intellectual- } \\
\text { Cultural }\end{array}$ & $.25(.00-.64)$ & $.28(.00-.57)$ & $.47(.34-.64)$ & 744.835 & 269 & 206.835 \\
\hline $\begin{array}{c}7) \text { Active- } \\
\text { Recreational }\end{array}$ & - & $.54(.00-.66)$ & $.46(.35-.59)$ & 731.153 & 270 & 191.153 \\
\hline $\begin{array}{c}\text { 8) Moral- } \\
\text { Religious }\end{array}$ & - & $.55(.42-.65)$ & $.45(.34-.57)$ & 715.920 & 270 & 175.920 \\
\hline 9) Organization & $.19(.00-.64)$ & $.38(.00-.63)$ & $.43(.30-.58)$ & 736.792 & 267 & 202.792 \\
\hline 10$)$ Control & $.26(.06-.44)$ & - & $.74(.55-.93)$ & 752.097 & 268 & 216.097 \\
\hline \hline I - Structure & $.73(.62-.81)$ & - & $.27(.18-.37)$ & 714.602 & 270 & 174.602 \\
\hline $\begin{array}{c}\text { II - Expressi- } \\
\text { veness }\end{array}$ & - & $.47(.33-.59)$ & $.53(.40-.66)$ & 722.625 & 266 & 190.625 \\
\hline III - Activities & $.21(.00-.65)$ & $.41(.00-.66)$ & $.38(.26-.52)$ & 738.170 & 269 & 200.170 \\
\hline
\end{tabular}

A, C, E - standardized variance components, - $2 \ln \mathbf{L}$ - fit index, $\mathbf{d f}$ - degrees of freedom for $-2 \mathrm{LnL}$ 


\section{Discussion}

The psychometrical properties of FES in our study will demand particular caution, when interpreting the results. The internal consistency is relatively acceptable for only 6 of the 10 scales. Nevertheless, our results are consistent with several previously published studies of the questionnaire's reliability. Chipuer and Villegas (2001) administered FES to a sample of adults of both sexes and reported low Chronbach's alphas for Expressiveness and Independence scales, as in our study. The same scales were found to have low internal consistency in the Gondoli and Jacob's (1993) study and even lower consistency in the cross cultural study of FES on a Chinese sample (Ma \& Leung, 1990). Boyd and colleagues (1997) conducted a study of validity of FES on a large sample of adolescents, concluding that reliability of most of the scales was found to be lower than acceptable. Sanford, Bingham, and Zucker (1999) examined the validity of FES using a sample of alcoholic families and found that only six scales corresponded to the standards of psychometrics: Expressiveness, Independence, Achievement Orientation, and Control scales had an unacceptable level of internal consistency almost the same as in our study. As it has been noted above, the original questionnaire's author (Moos, 1990) did not consider its rather modest psychometric properties as a crucial obstacle for using FES in research and clinical contexts.

The results of model-fitting display a differentiated picture of genetic and environmental factors that affect the variance of FES scales and super-order factors. Overall, environmental influences are prevalent, with the none-shared environment (that would include all environmental factors which make siblings differ from one another) being the most important kind of variance. The influence of the shared environment (environmental effect that make siblings more similar) was found to be significant for three scales (Expressiveness, Achievement Orientation, and Moral-Religious Orientation) as well as the Expressiveness-Control super-order factor. The complementary genetic effects were significant for two scales (Conflict and Control) and the Organization factor. The heritabilities on all other scales were in the low to modest range (around .22 on average). These findings come in tune with the results of previously published studies (Herndon et al., 2005; Hur \& Bouchard, 1995; Rowe, 1983). However, it is important to note that the statistical power of our 
study is not high enough to discern between complementary genetic and shared environment components for most of the scales, as well in choosing the right model. At the same time, the heritabilities for the two scales and one super-order factor from our study were found to be statistically significant, and, as such, deserve a more detailed discussion.

We've suggested a few hypotheses based on publications on behavior genetics of perceived family environment to interpret our findings. To begin with, we may presume that children's reports on the family environment do not reflect anything relevant, but are the "imprints" of personality traits - at least some of which appear to develop under genetic influence. In other words, as Plomin and Bergeman (1991) stated, reports on the environment might be reflecting projections of genetically influenced dispositions. The results from several studies (Chipuer, Plomin, Pedersen, McClearn, \& Nesselroade, 1993; Krueger, Markon, \& Bouchard, 2003; Saudino, Pedersen, Lichtenstein, McClearn, \& Plomin, 1997; Spotts et al., 2001) provide rather limited support for this hypothesis. An alternative (and more environmental) explanation could be a situation in which the pairs of MZ twins systematically develop a more coherent picture - a "scheme" of their environment - than DZ twins. If proven, we would conclude that violation of the equal environments assumption (which forms the basis for the analysis of variance in behavior genetics) occurred in the studied phenotype. So far, we do not have the relevant data to prove or refute this hypothesis. Indirect evidence related to this topic comes from studies of within-pair differences in twins' and siblings' perceptions of the environment (Feinberg, Neiderhiser, Howe, \& Hetherington, 2001; Pike, Manke, Reiss, \& Plomin, 2000; Reiss et al., 2000). The level of within-pair agreement, as it has been revealed, was relatively low for all kinds of twins and siblings, and the similarities of reports are not due to a commonly developed cognitive scheme, but are to some extent correlated with the objective differences found by external observers.

Besides, we may assume, that the assessments given to the family by each of the twins are relevant - i.e., they reflect some really important characteristics of family relationships for each member of the pair from his/her individual perspective. In this case, certain forms of the gene-environment correlation can be regarded as interpretations. As proposed by Plomin, Defries, and Loehlin (1977), three types of geneenvironment correlation can exist: passive (children receive a special 
kind of environment from parents due to common genes), active (children actively select the environments in correspondence with their genetic predispositions), and evocative (children provoke other people to react in a certain way to the genetically influenced patterns of behavior). For example, parents of MZ twins could treat them in a more similar manner because of the children's similarities in temperament and / or other genetically influenced personality traits. As it was roughly outlaid by Scarr and McCartney (1983), people may actively construct environments consistent with their genetic predispositions. Although we consider such statements to be overly general and primitive, we believe that more empirical studies are needed to discover the concrete types of gene-environment correlation at work, if any exists. This problem could be solved only by means of a longitudinal design (e.g., McGue et al., 2005) that allows the investigation of time-ordered sequences of parents' and their children's behavior.

\section{Conclusions}

Our study has revealed a differential picture of genetic and environmental effects on the variance of perceived family environment in Russian adolescent twins. The environmental variance components are prevalent for the most ( 6 of 10) of the FES scales. The shared environment was significant for three primary scales and the Structure factor, while the complementary genetic variance was significant for two primary scales and the Expressiveness-Control super-order factor. The results obtained herein are generally consistent with previously reported moderate heritability of FES scales, although the heritabilities for the Conflict scale and the Expressiveness-Control super-order factor appear to be relatively higher than those previously exposed. The gene-environment correlation might be a possible interpretation for our findings; longitudinal designs are required to pursue this hypothesis further.

\section{References}

Akaike, H. (1987). Factor Analysis and AIC. Psychometrika, 52, 317-332.

Barsky, Ph.I. (2007). Studies of Environment in Behavioral Genetics. In S.B. Malykh \& A.M. Torgersen (Eds.), Gene. Brain. Behavior (pp. 242-270). Moscow-Oslo: RP Press. 
Belsky, J., Bakermans-Kranenburg, M.J., \& van Ijzendoorn, M.H. (2007). For Better and for Worse: Differential Susceptibility to Environmental Influences. Current Directions in Psychological Science, 16, 300-304.

Bloom, B.L. (1985). A Factor Analysis of Self-Report Measures of Family Functioning. Family Process, 24, 225-239.

Bloom, B.L., \& Naar, S. (1994). Self-Report Measures of Family Functioning: Extensions of a Factorial Analysis. Family Process, 33, 203-261.

Boake, C., \& Salmon, P.G. (1983). Demographic Correlates and Factor Structure of the Family Environment Scale. Journal of Clinical Psychology, 39, 95-100.

Bouchard, T.J., \& McGue, M. (1990). Genetic and Rearing Environmental Influences on Adult Personality: An Analysis of Adopted Twins Reared Apart. Journal of Personality, 58, 263-292.

Boyd, C.P., Gullone, E., Needleman, M., \& Burt, T. (1997). The Family Environment Scale: Reliability and Normative Data for an Adolescent Sample. Family Process, 36, 369-373.

Champagne, F.A., \& Mashoodh, R. (2009). Genes in Context: Gene-Environment Interplay and the Origins of Individual Differences in Behavior. Current Directions in Psychological Science, 18, 127-131.

Chipuer, H.M., Plomin, R., Pedersen, N.L., McClearn, G.E., \& Nesselroade, J.R. (1993). Genetic Influence on Family Environment: The Role of Personality. Developmental Psychology, 29, 110-118.

Chipuer, H.M., \& Villegas, T. (2001). Comparing the Second-Order Factor Structure of the Family Environment Scale across Husbands' and Wives' Perception of their Family Environment. Family Process, 40, 187-198.

Cole, S.W. (2009). Social Regulation of Human Gene Expression. Current Directions in Psychological Science, 18, 132-137.

Daniels, D., \& Plomin, R. (1985). Origins of Individual Differences in Infant Shyness. Developmental Psychology, 21, 118-121.

Deater-Deckard, K., Fulker, D.W., \& Plomin, R. (1999). A Genetic Study of the Family Environment in the Transition to Early Adolescence. Journal of Child Psychology and Psychiatry, 40, 769-775.

Eidemiller, E.G., Dobryakov, I.V., \& Nikolskaya, I.M. (2003). Semeinyj diagnoz $i$ semeynaya psikhoterapya [Family Assessment and Family Therapy]. Saint Petersburg: Reč.

Feinberg, M., Neiderhiser, J., Howe, G., \& Hetherington, E.M. (2001). Adolescent, Parent, and Observer Perceptions of Parenting: Genetic and Environmental Influences on Shared and Distinct Perceptions. Child Development, 74, 1266-1284.

Fowler, P.C. (1981). Maximum Likelihood Factor Structure of the Family Environment Scale. Journal of Clinical Psychology, 37, 160-164. 
Gondoli, D.M., \& Jacob, T. (1993). Factor Structure within and across Three Family-Assessment Procedures. Journal of Family Psychology, 6, 278-289.

Halloran, E.C., Ross, G.J., \& Carey, M.P. (2002). The Relationship of Adolescent Personality and Family Environment to Psychiatric Diagnosis. Child Psychiatry and Human Development, 32, 201-216.

Herndon, R.W., McGue, M., Krueger, R.F., \& Iacono, W.G. (2005). Genetic and Environmental Influences on Adolescents' Perceptions of Current Family Environment. Behavior Genetics, 35, 373-380.

Hur, Y., \& Bouchard, T.J. (1995). Genetic Influences on Perceptions of Childhood Family Environment: A Reared Apart Twin Study. Child Development, 66, 330-345.

Jang, K.L., Vernon, P.A., Livesley, W.J., Stein, M.B., \& Wolf, H. (2001). Intra- and Extra-Familial Influences on Alcohol and Drug Misuse: A Twin Study of Gene-Environment Correlation. Addiction, 96, 1307-1318.

Kim-Cohen, J., \& Gold, A.L. (2009). Measured Gene-Environment Interactions and Mechanisms Promoting Resilient Development. Current Directions in Psychological Science, 18, 132-137.

Kronenberger, W.G., \& Thompson, R.J. (1990). Dimensions of Family Functioning in Families with Chronically Ill Children: A Higher Order Factor Analysis of the Family Environment Scale. Journal of Clinical Child Psychology, 19, 380-388.

Krueger, R.F., Markon, K.E., \& Bouchard, T.J. (2003). The Extended Genotype: The Heritability of Personality Accounts for the Heritability of Recalled Family Environments in Twins Reared Apart. Journal of Personality, 71, 809-834.

Loehlin, J.C. (2004). Latent Variable Models: An Introduction to Factor, Path, and Structural Equation Analysis (4th ed.). Mahwah, NJ: Lawrence Erlbaum Associates.

Loveland-Cherry, C.J., Youngblut, J.M., \& Kline-Leidy, N.W. (1989). A Psychometric Analysis of the Family Environment Scale. Nursing Research, 38, 262-266.

Ma, H.K., \& Leung, M.C. (1990). The Adaptation of the Family Environment Scale to Chinese Children and Adolescents in Hong Kong. International Journal of Psychology, 25, 545-555.

McGue, M., \& Bouchard, T.J. (1984). Adjustment of Twin Data for the Effects of Age and Sex. Behavior Genetics, 14, 325-343.

Moffitt, T.E., Caspi, A., \& Rutter, M. (2006). Measured Gene-Environment Interactions in Psychopathology: Concepts, Research Strategies, and Implications for Research, Intervention, and Public Understanding of Genetics. Perspectives on Psychological Science, 1, 5-27.

Moos, R.H. (1974). Family Environment Scale (Form R). Palo Alto, CA: Consulting Psychologists Press.

Moos, R.H. (1975). Assessment and Impact of Social Climate. In P. McReynolds (Ed.), Advances in Psychological Assessment. Vol. 3. San Francisco: Jossey-Bass. 
Moos, R.H. (1990). Conceptual and Empirical Approaches to Developing FamilyBased Assessment Procedures: Resolving the Cast of the Family Environment Scale. Family Process, 29, 199-209.

Moos, R.H., \& Moos, B.S. (1981). Manual: Family Environment Scale. Palo Alto, CA: Consulting Psychologists Press.

Moos R.H., \& Moos, B.S. (1994). A Social Climate Scale: Family Environment Scale manual. Development, Applications, Research (3rd ed.). Palo Alto: Consulting Psychologists Press, Inc.

Munet-Vilaro, F., \& Egan, M. (1990). Reliability Issues of the Family Environment Scale for Cross-Cultural Research. Nursing Research, 39, 244-247.

Neale, M.C., Boker, S.M., Xie, G., \& Maes, H.H. (2004). Mx: Statistical Modeling (6th ed.). VCU Box 900126, Richmond, VA 23298: Department of Psychiatry.

Neiderhiser, J.M., Reiss, D., \& Hetherington, E.M. (2007). The Nonshared Environment in Adolescent Development (NEAD) Project: A Longitudinal Family Sudy of Twins and Siblings from Adolescence to Young Adulthood. Twin Research \& Human Genetics, 10, 74-83.

Nichols, R.C, \& Bilbro, W.C. (1966). The Diagnosis of Twin Zygosity. Acta Genetica, 16, 265-275.

O’Connor, T.G., Hetherington, E.M., Reiss, D., \& Plomin, R. (1995). A Twin-Sibling Study of Observed Parent-Adolescent Interactions. Child Development, 66, 812-829.

Oliver, J.M., May, M.J., \& Handal, P.J. (1988). The Factor Structure of the Family Environment Scale: Factors Derived from Subscales. Journal of Clinical Psychology, 44, 723-727.

Pike, A., Manke, B., Reiss, D., \& Plomin, R. (2000). A Genetic Analysis of Differential Experiences of Adolescent Siblings across Three Years. Social Development, 9, 96-114.

Plomin, R., Asbury, K., \& Dunn, J. (2001). Why are Children in the Same Family so Different? Nonshared Environment a Decade Later. Canadian Journal of Psychiatry, 46, 225-33.

Plomin, R., \& Bergeman, C.S. (1991). The Nature of Nurture: Genetic Influence on "Environmental" Measures. Behavioral and Brain Sciences, 14, 373-427.

Plomin, R., Defries, J.C., \& Loehlin, J.C. (1977). Genotype-Environment Interaction and Correlation in the Analysis of Human Behavior. Psychological Bulletin, 84, 309-322.

Plomin, R., Loehlin, J.C., \& DeFries, J.C. (1985). Genetic and Environmental Components of "Environmental" Influences. Developmental Psychology, 21, 391-402.

Plomin, R., McClearn, G.E., Pedersen, N.L, Nesselroade, J.R., \& Bergeman, C.S. (1988). Genetic Influence on Childhood Family Environment Perceived Retrospectively from the Last Half of the Life Span. Developmental Psychology, 24, 738-745. 
Plomin, R., Reiss, D., Hetherington, E.M., \& Howe, G.W. (1994). Nature and Nurture: Genetic Contributions to Measures of the Family Environment. Developmental Psychology, 30, 32-43.

Reiss, D., Neiderhiser, J.M., Hetherington, E.M., \& Plomin, R. (2000). The Relationship Code: Deciphering Genetic and Social Influences on Adolescent Development. Cambridge, MA: Harvard University Press.

Roosa, M.W., \& Beals, J. (1990). Measurement Issues in Family Assessment: The Case of the Family Environment Scale. Family Process, 29, 191-198.

Rowe, D.C. (1981). Environmental and Genetic Influences on Dimensions of Perceived Parenting: A Twin Study. Developmental Psychology, 17, 203-208.

Rowe, D.C. (1983). A Biometrical Analysis of Perceptions of Family Environment: A Study of Twin and Singleton Sibling Kinships. Child Development, 54, 416-423.

Rutter, M. (2006). Genes and Behaviour: Nature-Nurture Interplay Explained. Blackwell Publishing, UK.

Rutter, M. (2007). Gene-Environment Interdependence. Developmental Science, $10,12-18$.

Rutter, M., Moffitt, T.E., \& Caspi, A. (2006). Gene-Environment Interplay and Psychopathology: Multiple Varieties but Real Effects. Journal of Child Psychology and Psychiatry, 47, 226-261.

Sanford, K.C., Bingham, R., \& Zucker, R.A. (1999). Validity Issues with the Family Environment Scale: Psychometric Resolution and Research Application with Alcoholic Families. Psychological Assessment, 11, 315-325.

Saucier, G., Wilson, K.R., \& Warka, J. (2007). The Structure of Retrospective Accounts of Family Environments: Related to the Structure of Personality Attributes. Journal of Personality Assessment, 88, 295-308.

Saudino, K.J., Pedersen, N.L., Lichtenstein, P., McClearn, G.E., \& Plomin, R. (1997). Can Personality Explain Genetic Influences on Life Events? Journal of Personality and Social Psychology, 72, 196-206.

Scarr, S., \& McCartney, K. (1983). How People Make their own Environments: A Theory of Genotype $\rightarrow$ Environmental Effects. Child Development, 54, 424-435.

Turkheimer, E., \& Waldron, M. (2000). Nonshared Environment: A Theoretical, Methodological, and Quantitative Review. Psychological Bulletin, 126, 78-108.

Waldron, R., Sabatelli, R., \& Anderson, S. (1990). An Examination of the Factor Structure of the Family Environment Scale. American Journal of Family Therapy, 18, 257-272. 